medRxiv preprint doi: https://doi.org/10.1101/2021.04.20.21255797; this version posted April 23, 2021. The copyright holder for this preprint (which was not certified by peer review) is the author/funder, who has granted medRxiv a license to display the preprint in perpetuity.

All rights reserved. No reuse allowed without permission.

\title{
Diagnostic accuracy of a novel SARS-CoV-2 antigen-detecting rapid diagnostic test from standardized self-collected anterior nasal swabs
}

\section{Authors:}

Bilgin Osmanodja, ${ }^{1} \mathrm{MD}$; Klemens Budde, ${ }^{1} \mathrm{MD}$; Daniel Zickler, ${ }^{1} \mathrm{MD}$; Marcel G. Naik, ${ }^{1,2} \mathrm{MD}$; Jörg Hofmann, ${ }^{3,4}$ MD; Maximilian Gertler, ${ }^{5}$ MD; Claudia Hülso, ${ }^{5}$ MD; Heike Rössig ${ }^{6}$; Philipp Horn ${ }^{6}$; Joachim Seybold, ${ }^{6}$ MD; Stephanie Lunow ${ }^{5}$; Melanie Bothmann ${ }^{5}$; Astrid Barrera-Pesek 5; Manuel Mayrdorfer, ${ }^{1} \mathrm{MD}$

1 Department of Nephrology and Medical Intensive Care, Charité - Universitätsmedizin Berlin, corporate member of Freie Universität Berlin, Humboldt-Universität zu Berlin, and Berlin Institute of Health, Berlin, Germany

${ }^{2}$ Berlin Institute of Health, Berlin, Germany

${ }^{3}$ Institute of Virology, Charité - Universitätsmedizin Berlin, corporate member of Freie Universität Berlin, Humboldt-Universität zu Berlin, and Berlin Institute of Health

${ }^{4}$ Labor Berlin - Charité Vivantes $\mathrm{GmbH}$, Berlin, Germany

${ }^{5}$ Institute of Tropical Medicine and International Health, Charité - Universitätsmedizin Berlin, corporate member of Freie Universität Berlin, Humboldt-Universität zu Berlin, and Berlin Institute of Health, Berlin, Germany

${ }^{6}$ Medical Directorate, Charité - Universitätsmedizin Berlin, corporate member of Freie Universität Berlin, Humboldt-Universität zu Berlin, and Berlin Institute of Health, Berlin, Germany

\section{Corresponding Author:}

Bilgin Osmanodja, MD

Department of Nephrology and Medical Intensive Care

Charité - Universitätsmedizin Berlin

Charitéplatz 1

Berlin, 10117

Germany

Phone: + 4930450614368

Email: bilgin.osmanodja@charite.de

Keywords: COVID-19; COVID-19 Diagnostic Testing; SARS-CoV-2; SARS-COV-2 Antigen Testing 
medRxiv preprint doi: https://doi.org/10.1101/2021.04.20.21255797; this version posted April 23, 2021. The copyright holder for this preprint (which was not certified by peer review) is the author/funder, who has granted medRxiv a license to display the preprint in perpetuity.

All rights reserved. No reuse allowed without permission.

\begin{abstract}
Background Antigen-detecting rapid diagnostic tests (Ag-RDT) for SARS-CoV-2 offer new opportunities for the quick and laboratory-independent identification of infected individuals for control of the SARS-CoV-2 pandemic. Despite the potential benefits, nasopharyngeal sample collection is frequently perceived as uncomfortable by patients and requires trained healthcare personnel with protective equipment. Therefore, anterior nasal self-sampling is increasingly recognized as a valuable alternative.
\end{abstract}

Methods We performed a prospective, single-center, point of care validation of an Ag-RDT using a polypropylene absorbent collector for standardized self-collected anterior nasal swabs. Real-Time Polymerase Chain Reaction (RT-PCR) from combined oropharyngeal/nasopharyngeal swabs served as a comparator. Primary endpoint was sensitivity of the standardized Ag-RDT in symptomatic patients with medium or high viral concentration ( $\geq 1$ million RNA copies on RT-PCR for SARS-CoV-2).

Results Between February 12 and March 22, 2021, 388 participants were enrolled. After exclusion of 9 patients for which no PCR result could be obtained, the novel Ag-RDT was evaluated based on 379 participants, of which 273 were symptomatic and 106 asymptomatic. In 61 samples from symptomatic patients with medium or high viral load ( $\geq 1$ million RNA copies), the sensitivity of the standardized Ag-RDT was $96.7 \%(59 / 61 ; 95 \% \mathrm{Cl}: 88.7-99.6 \%)$ for the primary endpoint. In total, 62 positive Ag-RDT results were detected out of 70 RT-PCR positive individuals, yielding an overall sensitivity of $88.6 \%(95 \% \mathrm{Cl}: 78.7-94.9 \%)$. Specificity was $99.7 \%$ (95\% Cl: 98.2-100\%) in 309 RT-PCR negative individuals.

Conclusion Here, we present a validation of a novel Ag-RDT with a standardized sampling process for anterior nasal self-collection, which meets WHO criteria of $\geq 80 \%$ sensitivity and $\geq 97 \%$ specificity. Although less sensitive than RT-PCR, this assay could be beneficial due to its rapid results, ease of use, and suitability for standardized self-testing.

(Funded by Drägerwerk AG \& Co. KGaA, Lübeck, Germany; ClinicalTrials.gov number NCT04698993)

\title{
Background
}

Various antigen-detecting rapid diagnostic tests (Ag-RDTs) for SARS-CoV-2 are now commercially available. ${ }^{1}$ Performed in an appropriate indication, they can support rapid decisions with respect to isolation, contact tracing, and treatment of patients with Covid-19. ${ }^{2}$

Since nasopharyngeal (NP) swabs are frequently perceived as uncomfortable by patients and must be collected by trained healthcare personnel, they are of limited use when establishing a population wide testing strategy. ${ }^{3}$ Fortunately, there is an increasing evidence base supporting the use of alternative sampling methods, including anterior nasal self-collection. ${ }^{4,5}$ This easier sample collection method can aid to achieve higher reliability of Ag-RDTs for self-testing.

The primary objective of this prospective diagnostic accuracy study was to assess sensitivity and specificity for a novel Ag-RDT with supervised, self-collected anterior nasal swab sample using a porous polypropylene absorbent collector against the reference standard RT-PCR collected from an oropharyngeal (OP)/NP swab.

\section{Methods}

The study protocol was approved by the ethical review committee of the federal state of Berlin and registered under ClinicalTrials.gov (NCT04698993). All experiments on human subjects were performed in accordance with the Declaration of Helsinki, implying that all participants provided informed consent. The study took place at two ambulatory SARS-CoV-2 testing 
medRxiv preprint doi: https://doi.org/10.1101/2021.04.20.21255797; this version posted April 23, 2021. The copyright holder for this preprint (which was not certified by peer review) is the author/funder, who has granted medRxiv a license to display the preprint in perpetuity.

All rights reserved. No reuse allowed without permission.

facilities at Charité - Universitätsmedizin Berlin, Germany, from February 12 to March 22, 2021. At study site A, symptomatic adults suspected of SARS-CoV-2 infection were enrolled, while at study site $\mathrm{B}$, asymptomatic and symptomatic employees and students were enrolled, participating in the regular hospital surveillance scheme. Main inclusion criterion for symptomatic patients was onset of COVID-19 symptoms within 7 days prior to testing. Main exclusion criteria were bleeding disorder, nasal spray application before testing, pregnancy and breastfeeding. Complete inclusion and exclusion criteria are provided in Table 1. Only participants with both an evaluable test result for the Ag-RDT and the RT-PCR reference standard were included in the analysis.

\begin{tabular}{|c|c|c|c|}
\hline & Inclusion Criteria & Exclusion Criteria \\
\hline \multicolumn{2}{|c|}{ General } & $\begin{array}{l}\text { - } \geq 18 \text { years old } \\
\text { - Written informed consent } \\
\text { - Pre-existing need for SARS- } \\
\text { CoV-2 testing, i.e. } \\
\circ \text { COVID-19 symptoms } \\
\circ \text { Known or suspected } \\
\text { exposure to SARS-CoV-2 } \\
\text { ○ Screening }\end{array}$ & $\begin{array}{l}\text { - }<18 \text { years old } \\
\text { - Unable to provide informed } \\
\text { consent } \\
\text { - Pregnant or breast-feeding } \\
\text { women } \\
\text { - Involuntarily held in an } \\
\text { institution } \\
\text { - Bleeding disorder } \\
\text { - Application of nasal spray prior } \\
\text { to testing on the day of testing } \\
\text { - Hospitalization/ inpatient } \\
\text { treatment }\end{array}$ \\
\hline \multirow[b]{2}{*}{ 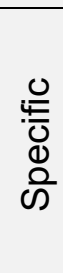 } & Asymptomatic & $\begin{array}{l}\text { - Asymptomatic during the } \\
\text { previous } 14 \text { days }\end{array}$ & $\begin{array}{l}\text { - COVID-19 symptoms during } \\
\text { the previous } 14 \text { days }\end{array}$ \\
\hline & Symptomatic & $\begin{array}{l}\text { - COVID-19 symptom(s) } \\
\text { present on the day of testing } \\
\text { - Symptoms started 0-7 days } \\
\text { prior to testina day }\end{array}$ & $\begin{array}{l}\text { - Symptoms started more than } 7 \\
\text { days prior to testing day }\end{array}$ \\
\hline
\end{tabular}

Table 1: Inclusion and exclusion criteria.

First, participants received a combined OP/NP swab (eSwab from Copan with $1 \mathrm{~mL}$ Amies medium) as per institutional recommendations for RT-PCR. Subsequently, participants underwent an instructed, self-collected bilateral anterior nasal swab for the Ag-RDT (Dräger Antigen Test SARS-CoV-2 by Dräger Safety AG \& Co. KGaA, Lübeck, Germany). The test comes as a one-piece test kit comprising a test cassette and a removable sample collector. The tip of the sample collector is a rigid, porous polypropylene sponge, which is used to swab the anterior nose and collect mucus and epithelial cells. After the general test procedure was explained to participants, verbal instruction was given to blow the nose once with a tissue. Next, the participants inserted the absorbent collector vertically $2-3 \mathrm{~cm}$ into the nostril and wiped the nasal walls in a circular motion for 30 seconds (Figure 1). This sampling process was repeated in the other nostril. After sampling, the sample collector was inserted and locked in the test cassette, where samples were analyzed immediately (within $15 \mathrm{~min}$ ) after sampling at point-of-care by study physicians according to the manufacturer's instructions. The test uses the lateral flow assay principle detecting SARS-CoV-2 nucleocapsid protein with visual readout after 15-20 minutes. The test cassette is a self-contained unit, which allows sample analysis while avoiding further contact with potentially infectious material and making handling of additional liquids, e.g. pipetting or dropping buffers, unnecessary. 


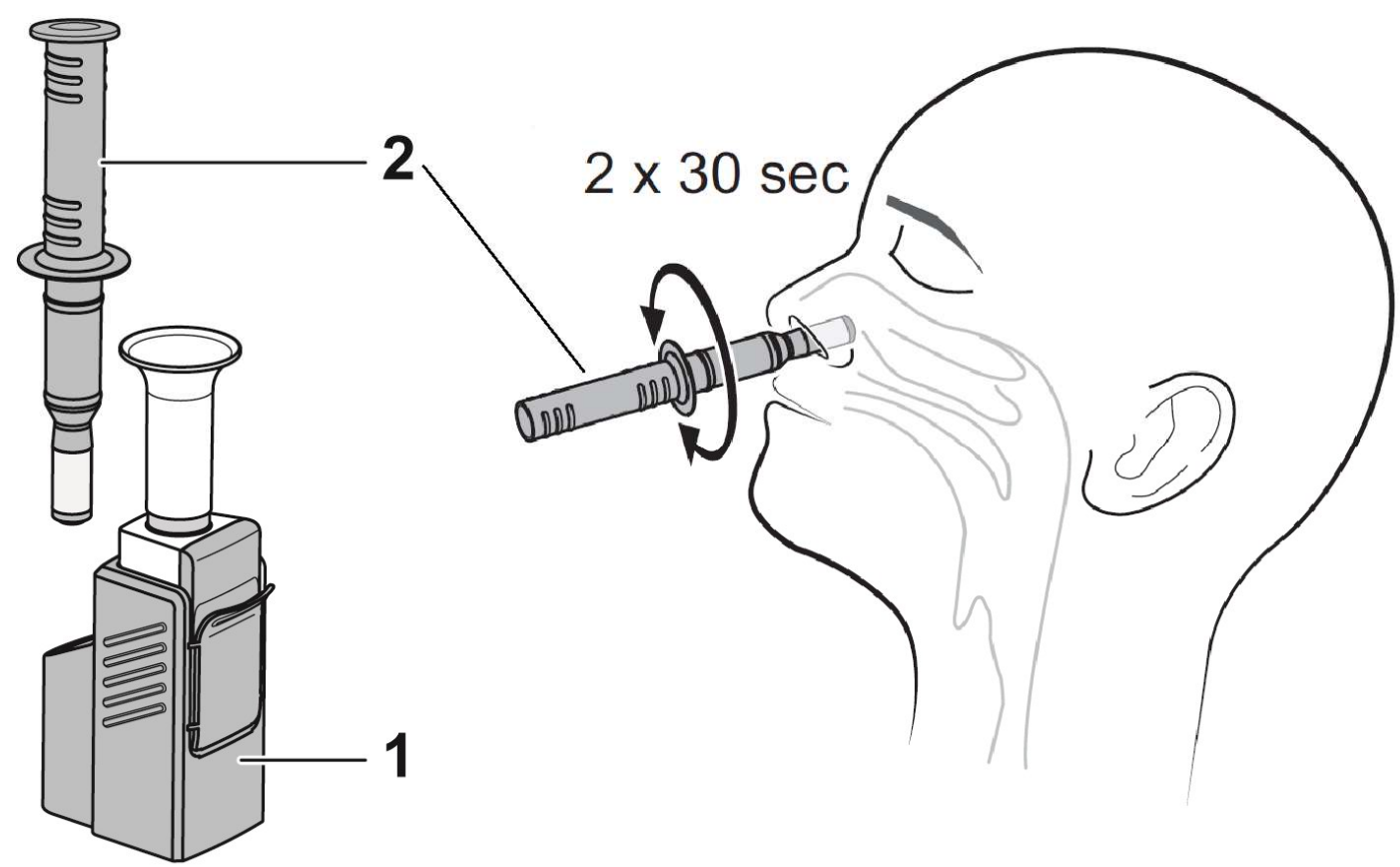

Figure 1: Sample collection - on the left, the test kit comprising a test cassette (1) and a removable sample collector (2) are shown. On the right, the sampling procedure is shown schematically.

The Roche Cobas SARS-CoV-2 assay (Pleasanton, CA, United States) was performed on a cobas $\AA 6800 / 8800$ analyzer (Roche Diagnostics, Mannheim, Germany) targeting both, orf1a/b (SARS-CoV-2) and E-gene (pan-Sarbecovirus). Viral concentration was classified into 3 categories (low: < 1 million, medium: 1 - 10 million, high: > 10 million RNA copies) based on standard preparations provided by Institute of Standardization, Düsseldorf, Germany. For all first-time diagnosed SARS-CoV-2 samples, typing for variants of concern (VoC) was performed, according to Phylogenetic Assignment of Named Global Outbreak (PANGO) Lineages classification. ${ }^{6}$

Primary endpoint was sensitivity of the novel Ag-RDT in symptomatic patients with medium or high viral concentration ( $\geq 1$ million RNA copies) on RT-PCR. ${ }^{7-9}$

Secondary endpoints were overall sensitivity and specificity, specificity in asymptomatic patients and frequency of nosebleed or unbearable pain due to specimen collection.

Data analysis was performed using the statistical programming language $R$, version 3.6.3. ${ }^{10}$ The $\mathrm{R}$ software package ggplot2 was used for data visualization. ${ }^{11}$ Sensitivity and specificity were determined, and the corresponding confidence intervals were calculated using the Clopper-Pearson method. Two-proportions $Z$ test was used for group comparison based on mutation status.

The study was stopped early, due to poor recruitment and Sponsor decision after 70 RT-PCR positive participants.

\section{Results}

Of 422 patients invited, 388 (91.9\%) consented to participate. Nine Ag-RDT negative participants ( $n=7$ asymptomatic, $n=2$ symptomatic) were excluded as no RT-PCR result could be obtained until the end of the study due to data protection issues. For another symptomatic patient, RT-PCR found RNA at the limit of detection, but repeated RT-PCR testing was negative, hence the patient was classified as RT-PCR negative. In summary, 379 patients 
medRxiv preprint doi: https://doi.org/10.1101/2021.04.20.21255797; this version posted April 23, 2021. The copyright holder for this preprint (which was not certified by peer review) is the author/funder, who has granted medRxiv a license to display the preprint in perpetuity.

All rights reserved. No reuse allowed without permission.

were included into the final analysis, of which 273 were symptomatic and 106 were asymptomatic (Figure 2).

The average age of participants was $34.0 \pm 10.8$ years with $53.3 \%$ female and $46.7 \%$ male. Among all participants, $14.0 \%$ had comorbidities. Duration of symptoms at the time of presentation was on average $2.8 \pm 1.8$ days among the 273 symptomatic patients. Among all 379 participants, $70(18.5 \%)$ tested positive for SARS-CoV-2 RNA, one of which was asymptomatic.

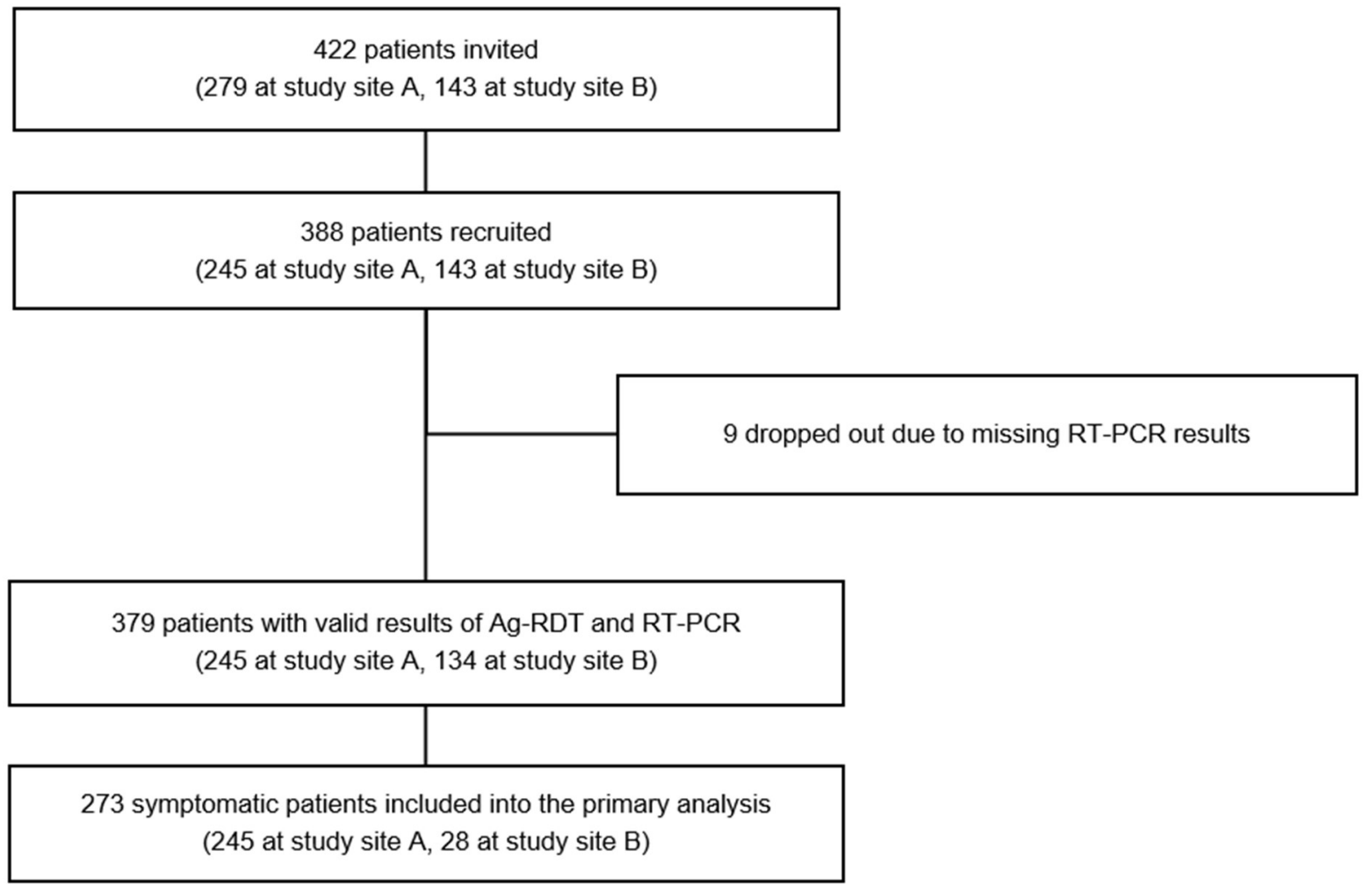

Figure 2: Participant Flow Diagram

\section{Primary endpoint}

In 61 symptomatic participants with medium or high viral concentration ( $\geq 1$ million RNA copies), the sensitivity of the Ag-RDT was $96.7 \%$ (59/61 RT-PCR positives detected; $95 \% \mathrm{Cl} 88.7 \%$ $99.6 \%)$. In 9 patients with low viral concentration ( $<1$ million copies) only 3 tested positive with the Ag-RDT test (Table 2).

\section{Secondary endpoints}

In total, the novel Ag-RDT showed a sensitivity of $88.6 \%$ (62/70 PCR positives detected; $95 \%$ Cl $78.7 \%-94.9 \%)$ as shown in Figure 3. Overall, specificity was 99.7\% (308/309 RNA negatives detected; $95 \% \mathrm{Cl}$ : $98.2 \%$ - 100\%) compared to RT-PCR.

Among the 106 asymptomatic participants, one tested positive on RT-PCR with a Ct-value of 31, but was negative on Ag-RDT. For the remaining 105 asymptomatic participants, who tested negative on RT-PCR, specificity of the Ag-RDT was $100 \%$.

Regarding mutation status, 44 participants were diagnosed with $\mathrm{VoC}$ B.1.1.7 and for the remaining 26 participants no $\mathrm{VoC}$ was found. Sensitivity of Ag-RDT among those patients with VoC B.1.1.7 was $88.6 \%(39 / 44)$ and did not differ significantly $(p=0.9075)$ from those without VoC, where sensitivity was $84.6 \%(22 / 26) .{ }^{6}$ 


\section{Safety and usability}

During the study, no adverse events and no invalid results on Ag-RDT occurred. Regarding usability, comfort and safety, $4.2 \%$ (16/379 participants) reported light pain during the selfcollection, but none reported strong or unbearable pain, and none developed nosebleed.

\begin{tabular}{|c|c|c|c|c|c|}
\hline Ct (E-Gen) & VC - copies & VoC & Ct (E-Gen) & VC - copies & VoC \\
\hline 13.7 & > 10 Mio & B.1.1.7 & 20.3 & > 10 Mio & none \\
\hline 14.1 & > 10 Mio & B.1.1.7 & 20.4 & > 10 Mio & B.1.1.7 \\
\hline 14.6 & > 10 Mio & B.1.1.7 & 20.5 & > 10 Mio & B.1.1.7 \\
\hline 14.7 & > 10 Mio & none & 20.7 & > 10 Mio & B.1.1.7 \\
\hline 14.7 & > 10 Mio & B.1.1.7 & 20.8 & > 10 Mio & B.1.1.7 \\
\hline 15.1 & > 10 Mio & B.1.1.7 & 21.1 & > $10 \mathrm{Mo}$ & B.1.1.7 \\
\hline 15.4 & > 10 Mio & B.1.1.7 & 21.2 & > 10 Mio & B.1.1.7 \\
\hline 15.5 & > 10 Mio & B.1.1.7 & 21.4 & > 10 Mio & none \\
\hline 15.7 & > 10 Mio & B.1.1.7 & 21.4 & > 10 Mio & B.1.1.7 \\
\hline 15.8 & > 10 Mio & none & 21.5 & > 10 Mio & none \\
\hline 15.9 & $>10$ Mio & B.1.1.7 & 21.5 & $>10$ Mio & B.1.1.7 \\
\hline 16.2 & > 10 Mio & B.1.1.7 & 22.4 & > 10 Mio & none \\
\hline 16.2 & > 10 Mio & B.1.1.7 & 22.4 & > 10 Mio & B.1.1.7 \\
\hline 16.3 & > 10 Mio & none & 22.5 & > 10 Mio & none \\
\hline 16.5 & > 10 Mio & none & 22.5 & > 10 Mio & none \\
\hline 16.5 & > 10 Mio & none & 22.6 & > 10 Mio & B.1.1.7 \\
\hline 16.8 & > 10 Mio & none & 22.7 & 1 - 10 Mio & none \\
\hline 17.1 & > 10 Mio & B.1.1.7 & 22.8 & > 10 Mio & none \\
\hline 17.1 & > 10 Mio & none & 24.0 & 1 - 10 Mio & B.1.1.7 \\
\hline 17.2 & > 10 Mio & B.1.1.7 & 24.2 & 1 - 10 Mio & B.1.1.7 \\
\hline 17.2 & > 10 Mio & B.1.1.7 & 24.4 & 1 - 10 Mio & none \\
\hline 17.8 & > 10 Mio & B.1.1.7 & 24.5 & 1 - 10 Mio & B.1.1.7 \\
\hline 17.8 & > 10 Mio & B.1.1.7 & 24.8 & 1 - 10 Mio & B.1.1.7 \\
\hline 17.9 & > 10 Mio & B.1.1.7 & 25.2 & 1 - 10 Mio & B.1.1.7 \\
\hline 18.4 & > 10 Mio & B.1.1.7 & 25.4 & $<1$ Mio & none \\
\hline 18.6 & > 10 Mio & B.1.1.7 & 25.4 & 1 - 10 Mio & none \\
\hline 18.9 & > 10 Mio & B.1.1.7 & 25.5 & 1 - 10 Mio & B.1.1.7 \\
\hline 19.2 & > 10 Mio & B.1.1.7 & 26.5 & < 1 Mio & B.1.1.7 \\
\hline 19.4 & > 10 Mio & B.1.1.7 & 27.7 & $<1$ Mio & None26 \\
\hline 19.5 & > 10 Mio & none & 27.8 & $<1$ Mio & B.1.1.7 \\
\hline 19.6 & > 10 Mio & none & 29.7 & $<1$ Mio & none \\
\hline 19.9 & > 10 Mio & none & 31.0 & $<1$ Mio & none \\
\hline 20.1 & > 10 Mio & B.1.1.7 & 33.0 & $<1$ Mio & B.1.1.7 \\
\hline 20.2 & > 10 Mio & B.1.1.7 & 33.3 & $<1$ Mio & none \\
\hline 20.3 & > 10 Mio & B.1.1.7 & 33.9 & $<1$ Mio & none \\
\hline
\end{tabular}

Table 2: Antigen-detecting RDT results with a supervised self-collected anterior nasal swab in 70 RNA positive patients from combined oropharyngeal/nasopharyngeal swab. Abbreviations: $\mathrm{Ct}$ - cycle threshold, VC - Viral concentration, VoC - Variant of Concern. Green - positive Antigen-detecting rapid diagnostic test. Red - negative Antigen-detecting rapid diagnostic test. 
medRxiv preprint doi: https://doi.org/10.1101/2021.04.20.21255797; this version posted April 23, 2021. The copyright holder for this preprint (which was not certified by peer review) is the author/funder, who has granted medRxiv a license to display the preprint in perpetuity.

All rights reserved. No reuse allowed without permission.

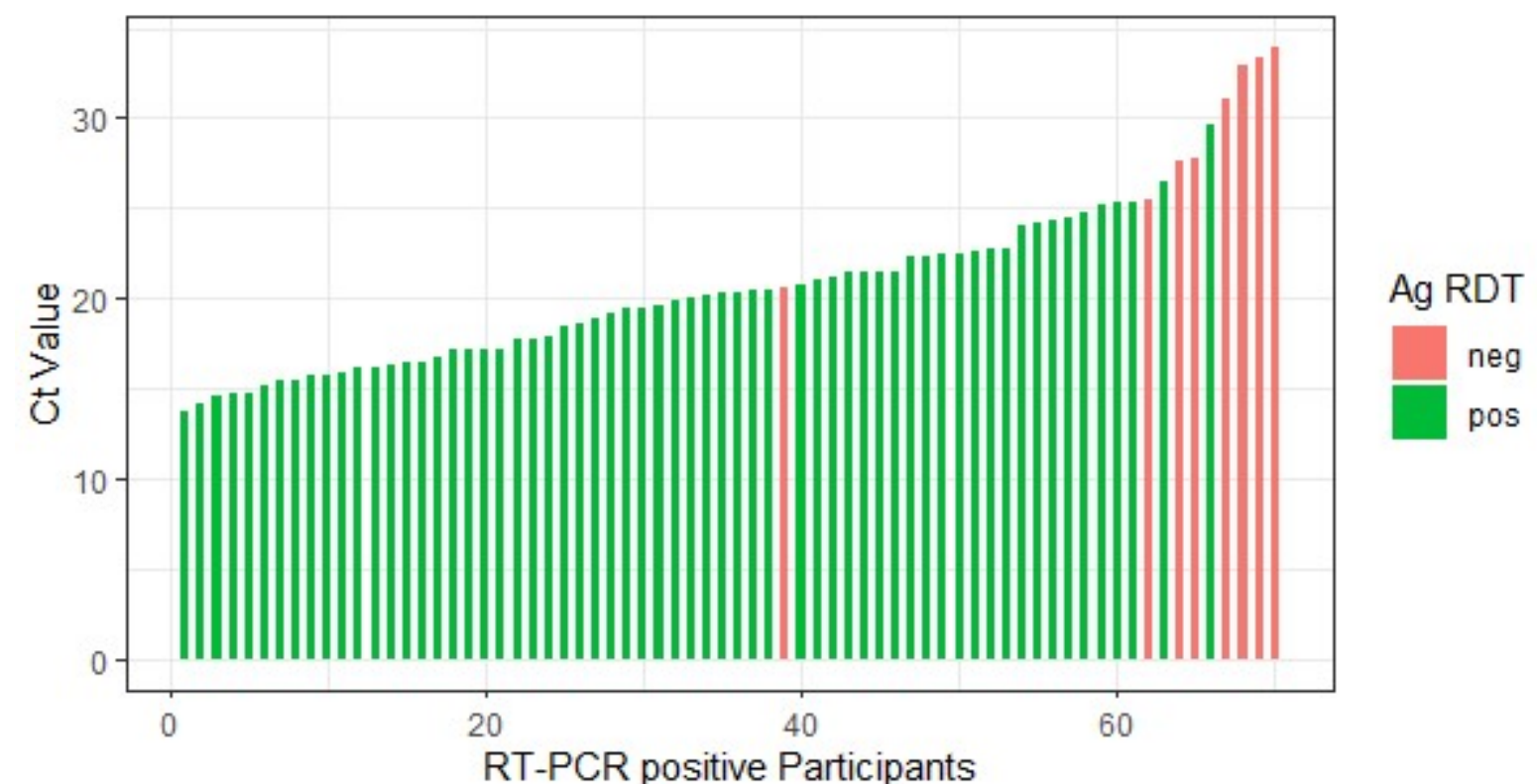

Figure 3: Bar plot showing Ag-RDT results and the corresponding Ct-values of 70 RT-PCR positive patients. Ct - Cycle threshold, Ag RDT (Antigen rapid diagnostic tests), neg negative, pos - positive, RT-PCR (Real-Time Polymerase Chain Reaction).

\section{Conclusion}

In this study, we demonstrated diagnostic accuracy of a novel Ag-RDT from self-collected anterior nasal swab, meeting the WHO criteria of $\geq 80 \%$ sensitivity and $\geq 97 \%$ specificity. ${ }^{2}$ Hereby, we follow other authors, who have demonstrated that supervised self-sampling from the anterior nose is a reliable option for Ag-RDT, yielding diagnostic accuracies comparable to those from nasopharyngeal swabs. ${ }^{4}$

In comparison to other Ag-RDTs, the standardized absorbent collector used in this study is a rigid, porous sponge, which might reduce variability in sampling method. While Ag-RDTs are rather reliable, the Achilles heel of testing, and in particular of anterior nasal swabs, is sampling procedure. Most Ag-RDTs for self-testing rely on flexible specimen collectors that can be used to perform anterior nasal, mid-turbinate or nasopharyngeal sample collection. In contrast, using a standardized sampling procedure designed for anterior nasal testing may result in less variability, which is of utmost importance for the reliability of self-testing. Additionally, since the test comes as self-contained device comprising all required biochemical reagents and the dilution buffer to carry out the test, the risk of contamination in the case of supervised selftesting is minimized for the testing personnel.

When compared to results from other test accuracy studies, the overall sensitivity of $88.6 \%$ found in our study is higher than the one reported in a recent systematic review, where the average sensitivity of Ag-RDTs in the first week after symptom onset was $78.3 \% .{ }^{12}$ Among those patients with medium or high viral concentration, sensitivity in our study was $96.7 \%$, which is comparable to the average sensitivity of $94.5 \%$ among patients with Ct values of $\leq 25$ reported in the same review. ${ }^{12}$ Among 106 asymptomatic participants, which we included in our study, only one tested positive on RT-PCR with a Ct-value of 31, but was negative on AgRDT. The remaining 105 participants were correctly tested negative, which together with the overall sensitivity of $99.7 \%$, makes positive results of this Ag-RDT highly reliable. Still, this emphasizes the importance of patient selection for Ag-RDT. While Ag-RDT are of high sensitivity in the first week of disease, their sensitivity in the second week or among asymptomatic patients is only $51.0 \%$ or $58.1 \%$, respectively. ${ }^{12}$ 
medRxiv preprint doi: https://doi.org/10.1101/2021.04.20.21255797; this version posted April 23, 2021. The copyright holder for this preprint (which was not certified by peer review) is the author/funder, who has granted medRxiv a license to display the preprint in perpetuity.

All rights reserved. No reuse allowed without permission.

Limitations of our study arise due to the fact, that OP/NP testing for RT-PCR was performed before Ag-RDT due to organizational reasons at the testing facility. Theoretically, this could transfer virus from the nasopharyngeal space to the anterior nose, but seems of little practical relevance since all patients were instructed to blow their nose to increase viral load in the anterior nose in any case. Another limitation in our and other studies is that Ct-values and viral concentration estimation are highly dependent on sample quality. In our study, experienced medical staff performed sampling and further processing was almost identical for all samples. We used a cutoff of 1 million copies for the primary endpoint for two reasons. First, an internal standard of 1 million RNA copies was tested as a one-point calibration with each PCR run. Second, in addition to technical reasons, viral concentrations below 1 million RNA copies indicate a lack of contagiosity in the late phase of Covid-19, and can be used to guide isolation measures according to German healthcare authorities. ${ }^{7-9}$

Considering the ease-of-use of Ag-RDTs, self-sampling and patient self-testing is the main future use case for such tests. The standardized sampling and test procedure of the Ag-RDT investigated in this study may allow for more reliable self-testing, which can increase testing frequency and can have significant impact on the pandemic.

\section{Acknowledgements}

We thank Sabrina Pein, Stefan Kruska, Silke Kasbohm, Nicole Walendowski and Rene Nadolny for their support.

Marcel G. Naik is participant in the BIH-Charité Digital Clinician Scientist Program funded by the Charité - Universitätsmedizin Berlin and the Berlin Institute of Health.

\section{Competing Interest}

The authors declare no competing interest.

\section{Funding Statement}

This study was funded by Drägerwerk AG \& Co. KGaA, Lübeck, Germany.

\section{Author contributions}

$\mathrm{BO}$ and $\mathrm{MM}$ designed the study and organized the study sites. $\mathrm{KB}$ and MG contributed to the study design. $B O, K B, M G N$, and $D Z$ enrolled patients, and performed the investigation. $H R$, $\mathrm{MG}, \mathrm{CH}$, and JS coordinated and supervised the testing facilities. SL, MB, PH, ABP ran the testing facilities and performed the comparative investigation. $\mathrm{BO}$ and $\mathrm{MM}$ led the data analysis. $\mathrm{JH}$ was responsible for PCR testing and contributed to the interpretation of the data. $\mathrm{DZ}$ was the principle investigator of the study. $\mathrm{BO}, \mathrm{KB}, \mathrm{MM}$, and $\mathrm{JH}$ wrote the manuscript. All authors have reviewed the final manuscript.

\section{References:}

1. Foundation of Innovative New Diagnostics (FIND). SARS-COV-2 Diagnostics Pipeline. http://www.finddx.org/covid-19/pipeline/

2. SARS-CoV-2 antigen-detecting rapid diagnostic tests: an implementation guide. Geneva: World Health Organization. 2020;

3. Lambert-Niclot S, Cuffel A, Le Pape S, et al. Evaluation of a Rapid Diagnostic Assay for Detection of SARS-CoV-2 Antigen in Nasopharyngeal Swabs. J Clin Microbiol. Jul 23 2020;58(8)doi:10.1128/JCM.00977-20

4. Lindner AK, Nikolai O, Kausch F, et al. Head-to-head comparison of SARS-CoV-2 antigen-detecting rapid test with self-collected nasal swab versus professional-collected nasopharyngeal swab. Eur Respir J. Feb 25 2021;doi:10.1183/13993003.03961-2020 
medRxiv preprint doi: https://doi.org/10.1101/2021.04.20.21255797; this version posted April 23, 2021 . The copyright holder for this preprint (which was not certified by peer review) is the author/funder, who has granted medRxiv a license to display the preprint in perpetuity.

All rights reserved. No reuse allowed without permission.

5. Nagura-Ikeda M, Imai K, Tabata S, et al. Clinical Evaluation of Self-Collected Saliva by Quantitative Reverse Transcription-PCR (RT-qPCR), Direct RT-qPCR, Reverse TranscriptionLoop-Mediated Isothermal Amplification, and a Rapid Antigen Test To Diagnose COVID-19. J Clin Microbiol. Aug 24 2020;58(9)doi:10.1128/JCM.01438-20

6. Rambaut A, Holmes EC, O'Toole A, et al. A dynamic nomenclature proposal for SARSCoV-2 lineages to assist genomic epidemiology. Nat Microbiol. Nov 2020;5(11):1403-1407. doi:10.1038/s41564-020-0770-5

7. IBBS. COVID-19: Entlassungskriterien aus der Isolierung. Robert Koch-Institut; 2021. p. 1.

8. van Kampen JJA, van de Vijver D, Fraaij PLA, et al. Duration and key determinants of infectious virus shedding in hospitalized patients with coronavirus disease-2019 (COVID-19). Nat Commun. Jan 11 2021;12(1):267. doi:10.1038/s41467-020-20568-4

9. Wolfel R, Corman VM, Guggemos W, et al. Virological assessment of hospitalized patients with COVID-2019. Nature. May 2020;581(7809):465-469. doi:10.1038/s41586-0202196-x

10. Team RC. R: A language and environment for statistical computing. $R$ Foundation for Statistical Computing, Vienna, Austria. 2020;

11. Wickham H. ggplot2: Elegant Graphics for Data Analysis. Springer-Verlag New York; 2016.

12. Dinnes J, Deeks JJ, Berhane S, et al. Rapid, point-of-care antigen and molecular-based tests for diagnosis of SARS-CoV-2 infection. Cochrane Database Syst Rev. Mar 24 2021;3:CD013705. doi:10.1002/14651858.CD013705.pub2 


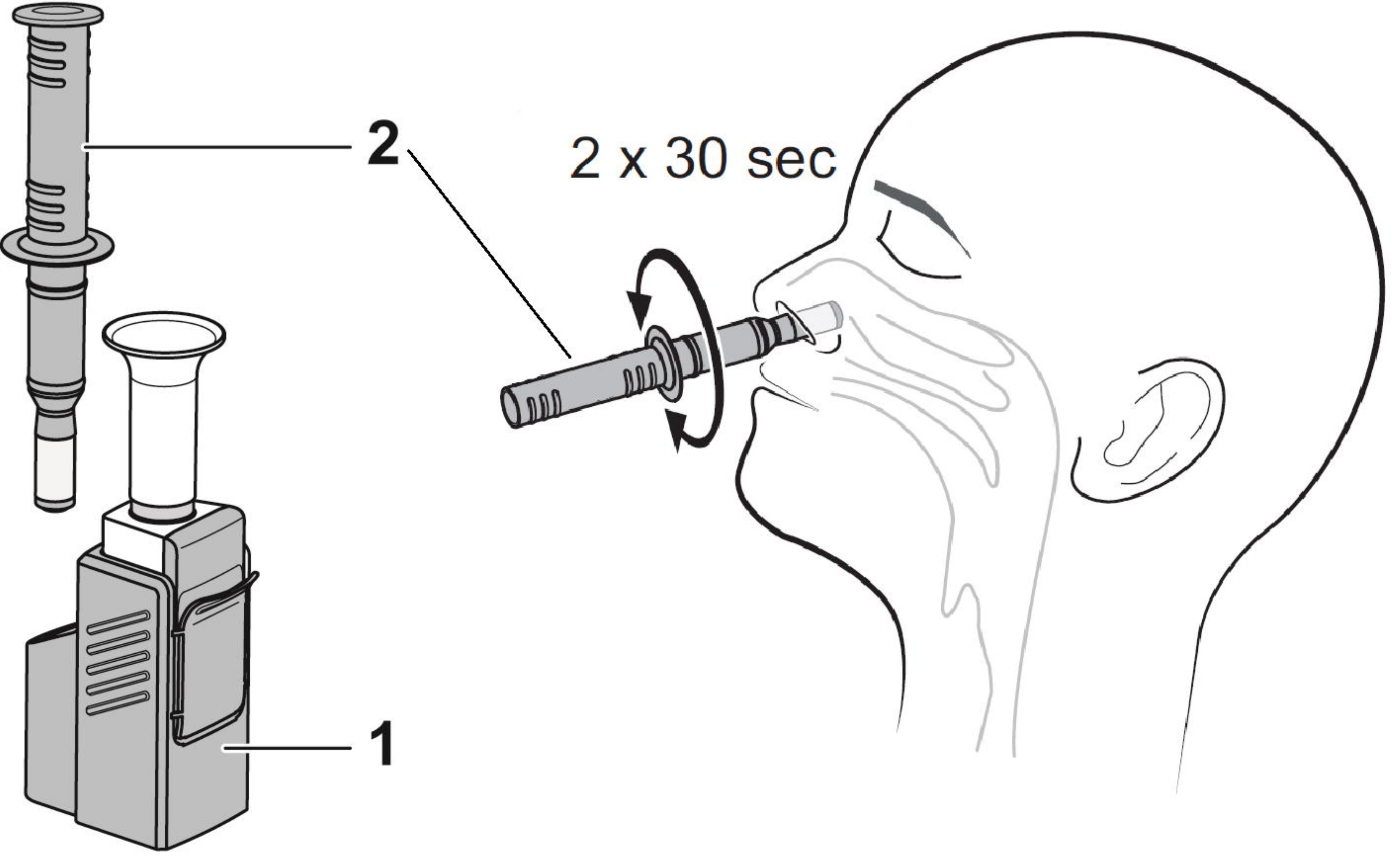




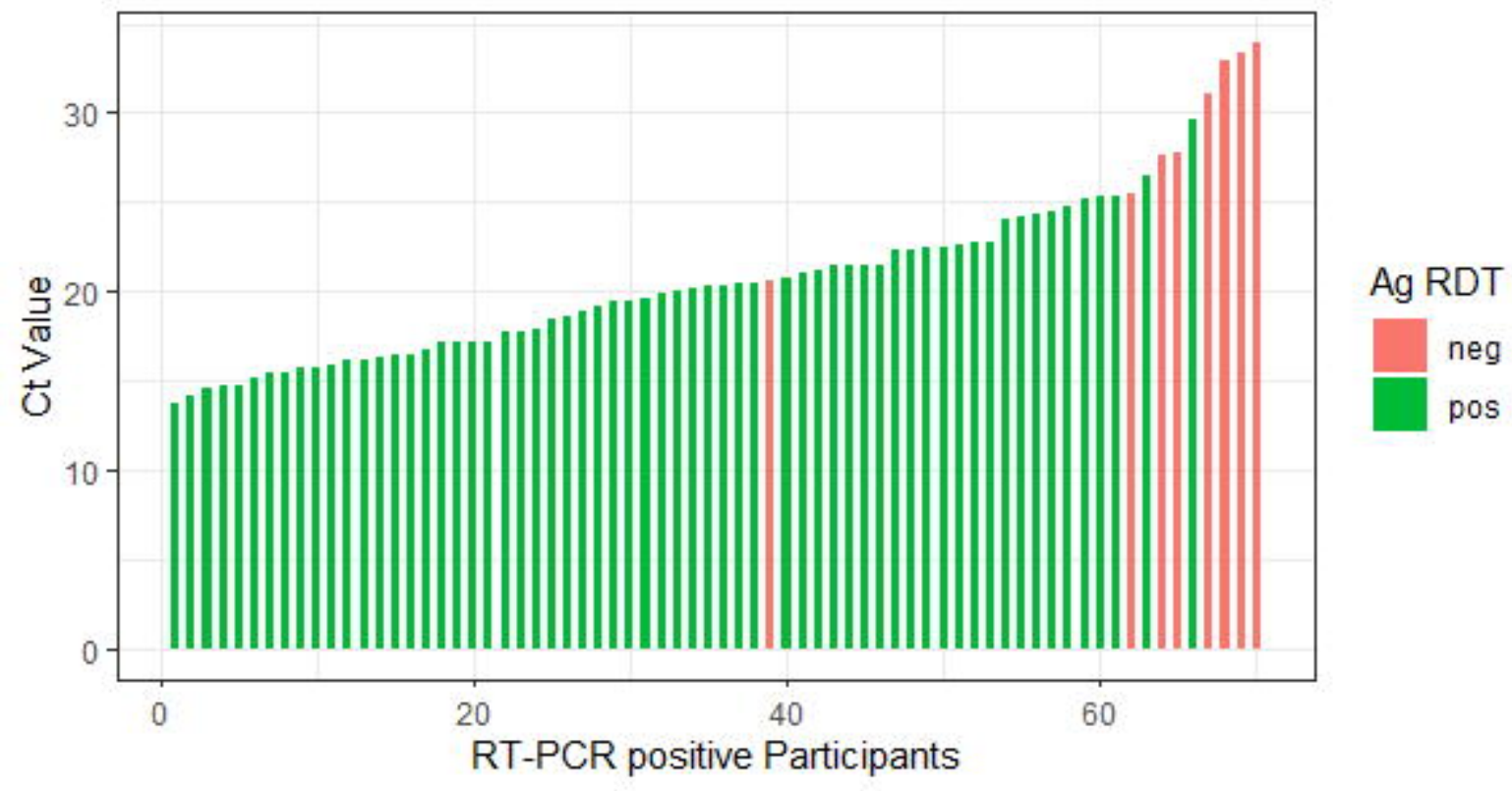

